\title{
Reviewer List
}

Loes Aaldering

Melinda Adams

Petra Ahrens

Nadje Al-Ali

Mathias Albert

Amy Alexander

Nikol Alexander-Floyd

Peter Allen

Alba Alonso

Sara Angevine

Michele Angrist

Elisabeth Anker

Dunja Antunovic

Sarah Anzia

Yesim Arat

Christie Arendt

Sahla Aroussi

Olga A. Avdeyeva

Erin Baines

Lisa Baldez

Noa Balf

Lee Ann Banaszak

Alexa Bankert

Tiffany Barnes

Sylvia Bashevkin

Amrita Basu

Alaka Basu

Gretchen Bauer

Nichole Bauer

Jane Bayes

Christine Beasley

Emily Beaulieu

Orly Benjamin
Helen Berents

Chantal Berman

Rachel Bernhard

Flávia Biroli

Robert Blanton

Elizabeth Borland

Mary Anne Borrelli

Angela Bos

Eileen Botting

Lorna Bracewell

Tristan Bridges

David Broockman

Nadia E. Brown

Lisa Brush

Barry Burden

Susan Burgess

Barbara Burrell

Ladislav Cabada

Rosie Campbell

Diana Carlin

Erin Cassese

Andrea Chandler

Cynthia Chavez Metoyer

Cristina Chiva

Seo-Young Cho

Ray Christensen

Cristina Cielo

Kursat Cinar

Jennifer Clark

Papavero Licia Claudia

Amanda Clayton

Alan Coffee

Dara Cohen 
Meredith Conroy

Simten Cosar

Kimberly Cowell-Meyers

Stephen Craig

Melody Crowder-Meyer

Pauline Cullen

Drude Dahlerup

Louise Davidson-Schmich

Todd Davies

Heath Davis

Grace Deason

Marc Debus

Debra Delaet

Nicole Detraz

Shirin Deylami

Christine Di Stefano

Sarah C. Dingler

Kathleen Dolan

Joshua Dubrow

Kevin Duong

Benedetta Faedi Duramy

Mary Ellsberg

R. Amy Elman

Rayya El Zein

Cynthia Enloe

Laurenz Ennser-Jedenastik

Justin Esarey

Maria Escobar-Lemmon

Lawrence Ezrow

Kathleen Fallon

Kennan Ferguson

Michaele Ferguson

Kathy Ferguson

Hawley Fogg-Davis

Olle Folke

Summer Forester

Jessica Fortin-Rittberger

Susan Franceschet

Lenita Freidenvall

Kim Fridkin
Gesine Fuchs

Sarah Fulton

Kendall Funk

Carol Galais

Yvonne Galligan

Emanuela Garboni

Alisa Gaunder

Caron Gentry

Sarah Allen Gershon

Elisabeth Gidengil

Nathalie Giger

Ti Gizelis

Sona Golder

Benjamin Goldfrank

Maciej Górecki

Paul Gorski

Amel Grami

Judith Grant

Tricia Gray

Karen Green

Jill S Greenlee

Anna Gwiazda

Liesl Haas

Richard Haesly

Donald Haider-Markel

Allison Harell

Heather Hartung-Macrae

Danny Hayes

Stephan Heichel

Virginia Held

Ranjoo Seodu Herr

Annie Hill

Helen Hill

Nancy Hirschmann

Anne Maria Holli

Mirya Holman

Valerie Hudson

Morten Huse

Fulden İbrahimhakkıoğlu

Jill Irvine 
Cecilia Jacob

Houri Jahanshahrad

Rita Jalali

Farida Jalalzai

Anne Jenichen

M. Jennings

Francesca R. Jensenius

Jutta Joachim

Livia Johannesson

Janet Johnson

Philip Jones

Julia S. Jordan-Zachery

Devin Joshi

Deniz Kandiyoti

Alice Kang

Kristin Kanthak

Nükhet Kardam

Mary Katzenstein

Kerwin Kaye

Lisa Keenan

Sarah Khan

Miki Kittilson

Samara Klar

Katherine R. Knobloch

Andrej Kokkonen

Zeynep Korkman

Andrea Krizsan

Corinna Kroeber

Mona Krook

Sonia Kruks

Sheri Kunovich

Jayati Lal

Janie Leatherman

Emanuela Lombardo

Maarja Luhiste

Maarja Lühiste

Fiona Mackay

Sveva Magaraggia

Melanie Magin

Devon Magliozzi
Charles Mahoney

Kathleen Marchetti

Kamil Marcinkiewicz

Lori Marso

Dyan Mazurana

Gail McElroy

Caroline McEvoy

Peace Medie

Lindsey Meeks

Erik Melander

Matthew Sinclair Mendez

Susan Mezey

Melissa Michelson

Geralyn Miller

William Mishler

Mari Miura

Valentine Moghadam

Kathleen Montgomery

Julie Moreau

Patricia Moynagh

Zein Murib

Aparna Nayak

Sohela Nazneen

Kjersten Nelson

Andrea Nichols

Isis Nusair

Kathleen Banks Nutter

Diana Z. O'Brien

Melanie O'Brien

Diana O'Brien

Mary Lou O'Neil

Patrik Öhberg

Tracy Osborn

Douglas Page

Jared Perkins

Patricia E. Perkins

Luke E. Perry

Helen Peterson

Jason Pierceson

Tim Prenzler 
Lesley Pruitt

Vicky Randall

A. Marie Ranjbar

Claire Rasmussen

Beth Reingold

Johanna Rickne

Fatima Sadiqi

Kira Sanbonmatsu

Juliana Restrepo Sanín

Brian Schaffner

Laurie Scheuble

Monica Schneider

Ronnee Schreiber

Druscilla Scribner

Francesca Scrinzi

Emily Shafer

Marwa Shalaby

Simona Sharoni

Sylvia Shaw

Laura Sjoberg

Inger Skjelsbæk

Katherine Smits

Valerie Sperling

Niels Spierings

Gabriele Spilker

Katelyn Stauffer

Daniel Stegmueller

Rita Stephan

Laura Stephenson

Walter Stone

Diane Sunar
Aksel Sundström

Aksel Sundström

Liam Swiss

Jonathan Symons

Mona Tajali

Shira Tarrant

Michelle Taylor-Robinson

Mari Teigen

Mark Tessler

Frank Thames

Melanee Thomas

Sue Tolleson-Rinehart

Aili Tripp

Joan C Tronto

Didem Unal

Melody Valdini

Laura Van Assendelft

Tània Verge

Mieke Verloo

Lihua Wang

Lena Wängnerud

Georgina Waylen

Ana Weeks

Bozena Welborne

Julia Welland

Julie White

Anne Whitesell

Christina Wolbrecht

Kristin Wylie

Michael Yarbrough

Hanna Ylöstalo 


\section{Politics \& Gender}

\section{INSTRUCTIONS TO CONTRIBUTORS}

Politics \& Gender accepts manuscript submissions through the Editorial Manager system at http://www.editorialmanager.com/pag.

For questions concerning "Instructions to Contributors," please contact the Editor at marycaputi@gmail.com. Additional information can be found at the journal's website at http://cambridge.org/pag.

\section{BOOK REVIEWS}

Suggestions of books to be reviewed should be emailed to the Book Review Editor:

\author{
Timothy V. Kaufman-Osborn \\ Politics \& Gender \\ Maxey Hall, Whitman College \\ 345 Boyer Ave. \\ Walla Walla, WA 99362, USA \\ pgbooks@whitman.edu
}

\section{MANUSCRIPT PREPARATION}

- Manuscripts must be no longer than 30 pages including text, tables and figures, references and appendices. The entire manuscript (including notes and references) must be doublespaced, with one-inch margins and 12-point font, and printed on one side of the page only.

- The author must include a separate title page, with his or her full contact information (including email address, telephone number and institutional affiliation), and a brief biographical statement. All identifying information must be removed from the manuscript.

- A second page must include an abstract of no more than 200 words.

- Placement of tables or figures should be cited in the text. The publisher will be responsible for placing artwork, tables or figures, as well as converting endnotes to footnotes.
- Appendices, tables, and figures should be numbered consecutively throughout the article and be included on separate pages appearing after the reference section. Figures should be ready for photographic reproduction; they cannot be redrawn by the publisher. Charts, graphs, or other artwork should be professional rendered or computer generated as TIFF or EPS files. Photographs should be clearly printed and should remain legible after a $50 \%$ reduction.

- References and notes should conform to the APSA Style Manual. Authors should include full volume, issue, and page numbers for references. Author's acknowledgments or other personal notes will appear as an unnumbered note at the foot of the first page. Notes should be numbered consecutively throughout the article. Numbered notes should appear at the end of the sentence. If multiple texts are cited in a sentence, they should appear as one consolidated note at the end of the sentence.

- All figure captions should be typed on a separate page (or pages), rather than on the figures themselves (which are camera-ready TIFF or EPS files) so that they can be copyedited.

Originality and copyright: Papers with multiple authors are reviewed with the assumption that all authors concur with its submission. A Copyright Transfer Agreement, with certain specified rights reserved by the author, must be signed and returned to the Editor by senior authors of accepted manuscripts, prior to publication. Politics \& Gender does not accept manuscripts for review that are under review elsewhere, previously published or already committed for publication.

For general guidelines for preparing a manuscript for submission, please refer to the APSA Style Manual for Political Science (rev. ed. 2001) for citation, footnotes, references, and other style issues. Please note, in particular, the statement on gender-specific language. 


\section{Politics \& Gender}

Volume 14 | Number 4 | December 2018

\section{ARTICLES}

Staying Tuned: LGBTQIA Politics in the Trump Era

Guest Edited by Susan R. Burgess, Marla Brettschneider,

and Christine (Cricket) Keating

Sexual Orientation and Gender Identity (SOGI) Human Rights

Assistance in the Time of Trump

Cynthia Burack

Queering Reproductive Justice in the Trump Era: A Note on Political Intersectionality

Kimala Price

Fagchild Tools: Softening the Body Politic and Sexualizing Paul Ryan in a Pussy-Grabbing Era

Queer J. Thomas

Trump in Transnational Perspective: Insights from Global LGBT Politics Julie Moreau

Trumpism, Citizenship, and the Future of the LGBTQ Movement

Zein Murib

CRITICAL PERSPECTIVES ON GENDER AND POLITICS

ONLINE THEMED BOOK REVIEWS

Staying Tuned: LGBTQIA Politics in the Trump Era

E17

\section{ONLINE BOOK REVIEW SYMPOSIUM}

Symposium Review: 25th Anniversary of Moral Boundaries by Joan Tronto 